\title{
Doctoral Degrees and Library Resources
}

\begin{abstract}
This paper brings up to date a similar report which was published in College \& Research Libraries in 1966 showing the relationship between library holdings and the number of doctoral degrees granted in several American universities. Correlation between the two remains high. Generally speaking, the strongest graduate offerings are at institutions with the strongest libraries.
\end{abstract}

\begin{abstract}
A
STUDY PUBLISHED in 1966 revealed a close relationship between doctoral degrees conferred by American universities and library resources and support. ${ }^{1}$ The recent publication of the 10th edition of American Universities and Colleges ${ }^{2}$ provides an opportunity to update the previous investigation. In a tabular summary of "Earned Doctorates, 1957-1966, by Field and Institution,"3 the ACE directory presents the number of degrees awarded by each institution. The figures are broken down further by broad categories: humanities, biological sciences, physical sciences, social sciences, and a miscellaneous group not classifiable by fields.
\end{abstract}

A total of 214 universities, colleges, seminaries, institutes, and schools are listed by American Universities and Colleges as having conferred five or more doctoral degrees during the decade 1957-66. For present purposes, only those institutions granting one hundred or more degrees in the course of the

\footnotetext{
1 College \& Research Libraries, XXVII (March 1966 ), 123-29, 141.

2 Washington: (ACE) American Council on Education, 1968.

Ibid., p. 1699-1702.
}

Dr. Downs is Dean of Library Administration in the University of Illinois. ten-year period are considered-a total of 120 universities or other institutions of higher education. The accompanying table includes the selected group, rearranged in the order of the number of degrees conferred. The two final columns report for each library the number of volumes held and the total expenditures for books, periodicals, and binding as of 1966, the final year covered by the ten-year record of statistics of doctoral degrees. ${ }^{4}$

According to the ACE summary, 121,750 doctoral degrees were granted by American universities and colleges during the decade. Of the total, 77,465 degrees, or about 64 per cent (nearly two-thirds), came from thirty-eight in stitutions with library holdings in excess of a million volumes each. The mean figure for the thirty-eight libraries was $2,135,565$ volumes.

A close correlation existed also between the number of degrees conferred and the level of financial support. The forty universities whose libraries spent more than $\$ 500,000$ each for books, periodicals, and binding in 1965-66 granted a total of 79,126 doctoral degrees, or 65 per cent of the whole figure of 121,750 .

4 The library data are based chiefly on Library Statistics of Colleges and Universities, 1965-66 (Chicago: American Library Association, 1967). 
The list of degree-granting institutions was headed by the University of California, which awarded 6,981 doctorates during the decade. The total represents seven campuses, but 4,869 degrees came from Berkeley and Los Angeles combined, both owning multi-million volume libraries.

Book collections and expenditures have continued to expand since the 1966 figures were compiled. As reported in the Association of Research Libraries" "Academic Library Statistics" for 1967-68, fifty-one of the seventy member libraries possessed more than a million volumes each and eleven more were on the verge of reaching the millionvolume level at the end of the year. In expenditures for books and binding, twenty-six of the seventy exceeded $\$ 1,000,000$ each for 1967-68; sixty of the seventy had book expenditures above $\$ 500,000$ for the year.

A distinction should be made among several principal types of institutions included in the select group of 120. First, there are the general universities, encompassing virtually all fields. Second, there are a score or more of former A. and $\mathbf{M}$. state colleges recently converted into general universities, since which time a majority have been actively engaged in developing major general libraries. Examples are Purdue, Iowa State, Pennsylvania State, Oregon State, Oklahoma State, Texas A. \& M., North Carolina State, Washington State, Kansas State, Auburn, Utah State, Colorado State, and Montana State. A third recognizable category is the specialized technical institutions-California Institute of Technology, Carnegie Institute of Technology, Polytechnic Institute of Brooklyn, Rensselaer Polytechnic Institute, Illinois Institute of Technology,
Virginia Polytechnic Institute, Case Institute of Technology, and Georgia Institute of Technology-which confer degrees primarily in the physical and biological sciences, and whose library requirements, therefore, are considerably less diverse than are those of general universities dealing with all fields. Another group of specialized institutions, a small one, is represented by the New School for Social Research, the Southwestern Baptist Theological Seminary, and the Union Theological Seminary.

Purely from a pragmatic point of view, one may conclude that quantitatively a library in a university offering comprehensive doctoral programs should possess a minimum of $1,500,000$ volumes and ought to be spending not less than $\$ 750,000$ annually for books, periodicals, and binding. Among the thirty-four universities which granted an average of one hundred doctorates a year, or more, during the 1957-66 period, twenty-two met the suggested standard for volume holdings, as of July 1, 1968, and twentynine of the thirty-four spent in excess of $\$ 750,000$ each for books.

In summary, statistics of doctoral degrees granted and of library holdings and book expenditures strongly support the view that there is a high degree of correlation between the two in universities distinguished for their doctoral programs. With rare exceptions, an institution outstanding for its graduate offerings is equally notable for the strength of its library resources. It is perhaps equally obvious that a number of institutions granting the doctorate lack the library resources to support advanced level graduate study and need to undertake extensive development of their libraries. 
Doctoral Degrees Awarded, 1957-1966, and Libraky Resources

\begin{tabular}{|c|c|c|c|c|c|c|c|c|c|c|c|}
\hline Institution & & & & $\begin{array}{l}\text { Total No. } \\
\text { Degrees }\end{array}$ & Humanities & $\begin{array}{l}\text { Biological } \\
\text { Sciences }\end{array}$ & $\begin{array}{l}\text { Physical } \\
\text { Sciences }\end{array}$ & $\begin{array}{c}\text { Social } \\
\text { Sciences }\end{array}$ & Miscellaneous & $\begin{array}{c}\text { Volumes in } \\
\text { Library, } 1966\end{array}$ & $\begin{array}{c}\text { Book } \\
\text { Expenditures } \\
1965-66\end{array}$ \\
\hline \multicolumn{4}{|c|}{ California (all campuses) } & 6,981 & 519 & 2,031 & 2,670 & 1,731 & 30 & $7,111,539$ & $\$ 5,254,125$ \\
\hline Columbia & . & . & . & 5,679 & 998 & 550 & 1,074 & 3,041 & 16 & $3,675,920$ & 927,775 \\
\hline Illinois . & .. & & . & 4,194 & 384 & 960 & 1,872 & 938 & 40 & $4,083,634$ & $1,744,763$ \\
\hline Wisconsin & . & . & . & 4,189 & 525 & 1,421 & 1,112 & 1,091 & 40 & $1,746,321$ & $1,107,503$ \\
\hline Harvard. & 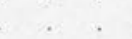 & . & . & 3,864 & 813 & 452 & 981 & 1,591 & 27 & $7,600,357$ & $1,596,989$ \\
\hline Michigan & & . & . & 3,395 & 563 & 744 & 1,175 & 872 & 41 & $3,516,355$ & $1,066,365$ \\
\hline New York Un & niversity & . & . & 3,225 & 420 & 556 & 676 & 1,567 & 6 & $1,648,437$ & 572,900 \\
\hline Ohio State & . & . & . & 2,960 & 292 & 859 & 869 & 940 & & $1,845,069$ & 622,734 \\
\hline Minnesota & 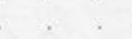 & . & . & 2,854 & 246 & 1,093 & 717 & 788 & 10 & $2,484,402$ & 866,343 \\
\hline Stanford . & 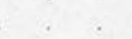 & . & . & 2,613 & 261 & 265 & 1,248 & 791 & 48 & $2,764,211$ & $1,074,801$ \\
\hline Purdue & & . & . & 2,565 & 21 & 1,102 & 1,145 & 296 & 1 & 770,666 & 615,439 \\
\hline Indiana & . & . & . & 2,542 & 419 & 280 & 332 & 1,504 & 7 & $1,943,256$ & $1,116,335$ \\
\hline Chicago & . & . & . & 2,469 & 370 & 409 & 576 & 1,077 & 37 & $2,445,141$ & 904,012 \\
\hline MIT & . & . & . & 2,424 & 31 & 119 & 2,128 & 146 & & 900,468 & 413,061 \\
\hline Yale & & . & . & 2,396 & 830 & 391 & 659 & 507 & 9 & $4,995,398$ & $1,420,206$ \\
\hline Michigan State & & . & . & 2,251 & 158 & 778 & 478 & 837 & & $1,224,528$ & 783,111 \\
\hline Cornell & & . & . & 2,132 & 208 & 891 & 456 & 571 & 6 & $2,892,539$ & $1,149,001$ \\
\hline Texas & & . & . & 1,957 & 235 & 356 & 732 & 634 & & $1,912,018$ & $1,002,131$ \\
\hline Iowa State & & . & . & 1,934 & 396 & 516 & 822 & 200 & & 586,627 & 291,379 \\
\hline Pennsylvania & (n) & . & & 1,809 & 311 & 298 & 533 & 657 & 10 & $1,958,602$ & 655,402 \\
\hline Pennsylvania S & State & . & . & 1,759 & 62 & 411 & 676 & 577 & 33 & 891,396 & 752,648 \\
\hline Northwestern & . & . & . & 1,650 & 456 & 204 & 606 & 384 & & $1,771,899$ & 529,006 \\
\hline Southern Calif & ifornia & . & . & 1,579 & 333 & 218 & 153 & 875 & & $1,192,240$ & 379,345 \\
\hline University of & Washing & ton & . & 1,568 & 221 & 378 & 596 & 365 & 8 & $1,466,906$ & 840,028 \\
\hline Princeton &.$\quad$. & . & . & 1,504 & 260 & 131 & 783 & 305 & 25 & $1,846,776$ & 671,953 \\
\hline Iowa & . & . & . & 1,362 & 27 & 396 & 352 & 587 & & $1,284,836$ & 623,896 \\
\hline Pittsburgh & 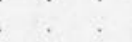 & . & . & 1,220 & 156 & 250 & 391 & 420 & 3 & 997,896 & 544,327 \\
\hline North Carolina & a & . & & 1,135 & 234 & 246 & 266 & 389 & & $1,385,234$ & 581,824 \\
\hline Maryland & w & . & . & 1,122 & 61 & 348 & 413 & 300 & & 754,108 & 742,962 \\
\hline Rutgers. & 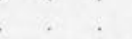 & . & . & 1,122 & 26 & 551 & 282 & 254 & 9 & $1,289,554$ & 612,619 \\
\hline Johns Hopkins & is . & . & . & 1,103 & 142 & 312 & 470 & 174 & 5 & $1,500,322$ & 320,361 \\
\hline Missouri & . & . & . & 1,083 & 98 & 296 & 231 & 458 & & $1,230,000$ & 486,049 \\
\hline Florida & . & . & . & 1,040 & 98 & 311 & 310 & 318 & 3 & $1,147,711$ & 574,396 \\
\hline Catholic & & . & . & 1,007 & 367 & 149 & 205 & 285 & 1 & 681,901 & 114,990 \\
\hline Colorado . & . & . & . & 961 & 79 & 161 & 369 & 352 & & $1,205,863$ & 668,698 \\
\hline Duke. & . & . & . & 957 & 174 & 282 & 223 & 278 & & $1,783,803$ & 611,870 \\
\hline Syracuse . & . & . & . & 941 & 64 & 131 & 254 & 385 & 107 & $1,262,051$ & 505,545 \\
\hline Louisiana & . . & & . & 867 & 78 & 364 & 217 & 208 & & $1,029,650$ & 418,770 \\
\hline
\end{tabular}




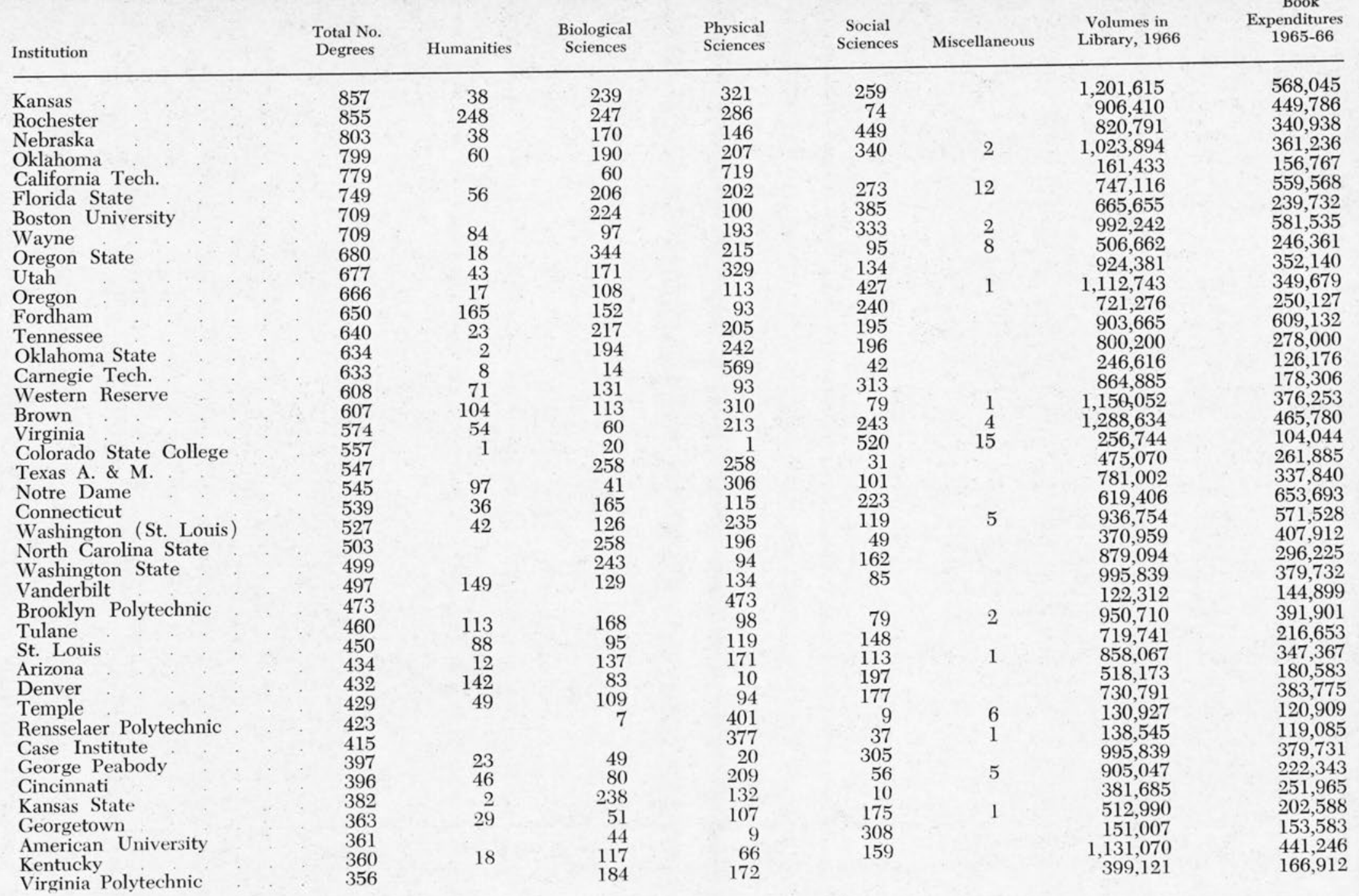




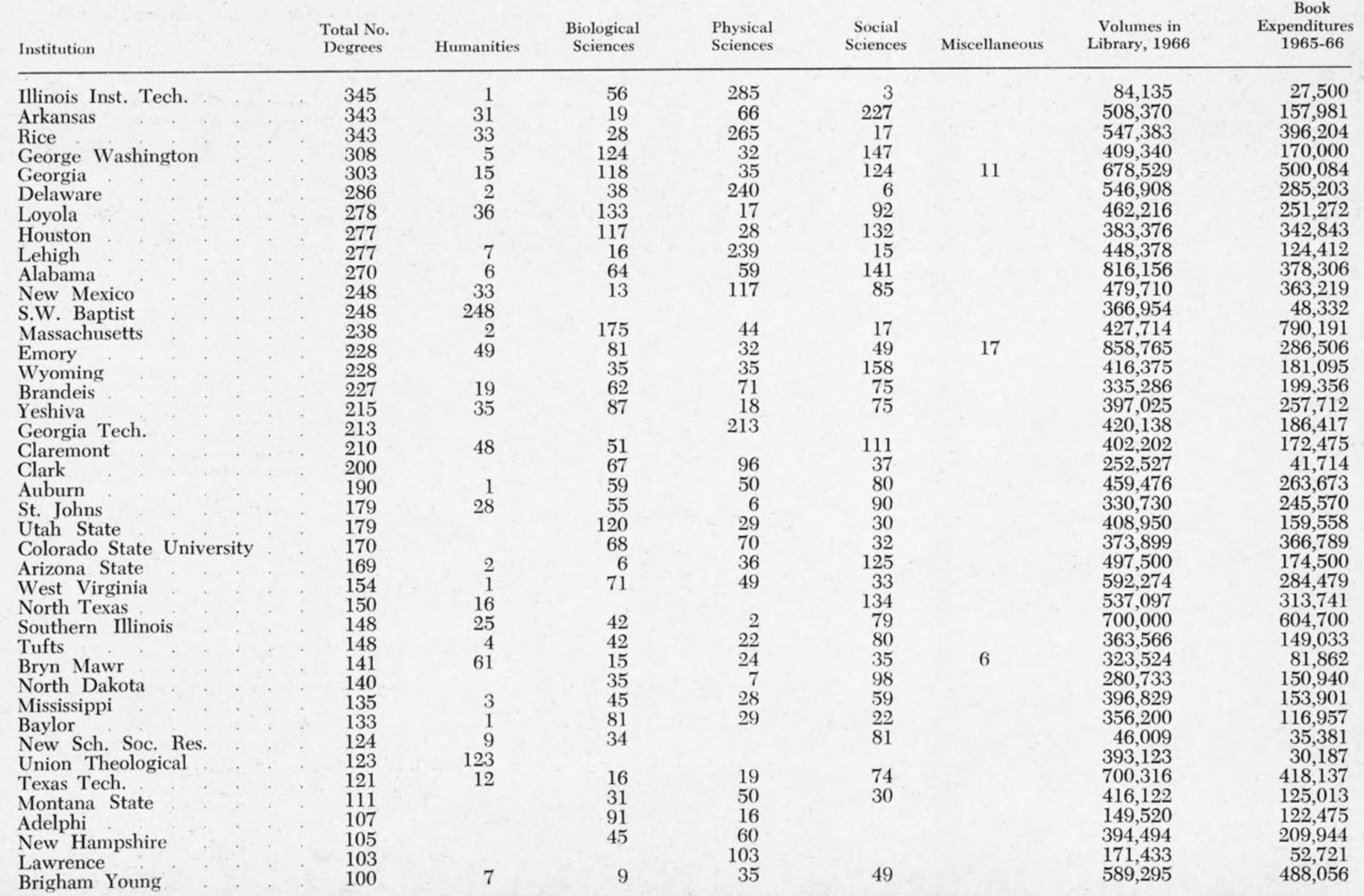

